Mediterranean Journal of Humanities mjh.akdeniz.edu.tr I/2, 2011, 73-85

\title{
The Interface between Critical Thinking Strategies and Moral Development
}

\author{
Eleştirel Düşünme ve Ahlaki Gelişimin Örtüşümü
}

Feryal ÇUBUKÇU*

\begin{abstract}
Fables can be excellent windows into the worlds of animals and human beings for children. Moreover, they are fun to read, discuss, envisage and personalize via storytelling. There have been many fable theorists who have reflected on the definition of fable and its different functions. John Locke recommended fables to teach language at a time when social concern was growing, particularly in education. In the same way, the fabulist La Fontaine also alluded to the instructive aspect or value of fables. Fables are kinds of instruction disguised under the allegory of an action with the purpose of moral teaching. One of the best known theories of moral development is associated with Lawrence Kohlberg (1971), and it suggests how art might lead to moral development. L. Kohlberg claims that there is empirical evidence which shows that there are universal ontogenetic trends towards the development of morality. He explicitly rejects views that moral development is the result of either teaching or maturation. He also argues that empirical studies have failed to confirm the findings of psychoanalytic schools; there are no correlations between parental modes of handling infantile drives and later behavior and attitudes. He holds, instead, that moral development is primarily the result of the interaction between the individual and their social environment, where role taking is of central importance. The aim of this paper is to show how Aesop's fables are used to enhance critical thinking strategies and to promote moral development.
\end{abstract}

Keywords: Fables, moral development, critical thinking strategies, education

Özet: Fabl çocuklar için hem hayvanlar hem de insan dünyasına açılan mükemmel bir pencere görevindedir. Bunun dışında, fablların, öykü anlatımıyla okunması, tartışılması, imgelenmesi ve kişileştirilmesi çok zevklidir. Fabl nedir ne değildir konusunda yazan sayısız eleştirmen ve düşünür vardır. Bunlardan biri olan John Locke sosyal konularda sorunun olduğu zamanlarda özellikle eğitimde dil öğretiminde fabl kullanımını tavsiye eder. Aynı şekilde La Fontaine de fablın eğitimsel yanını öne çıkartır. Gerçekte fabl, ahlaki ders verme amacıyla yazılmış olan ve alegorik özellik taşıyan öğütlerdir. Ahlaki gelişim kuramlarından birini savunan Lawrence Kohlberg sanatın ahlaki gelişmeye yardımcı olabileceğini belirtir. Ahlaki gelişimde evrensel eğilimler olduğunu gösteren deneysel deliller mevcut olduğunu ve ahlaki gelişimin öğretme veya büyümenin sonucu olduğunu savunan fikirlere şiddetle karşı çıkan L. Kohlberg (1971), deneysel çaıışmaların psikoanalitik ekollerin bulgularını çürüttüğünü de savunmaktadır: ebeveynlerin çocuklarının dürtüleriyle başa çıkma yollarıyla kişilerin sonraki davranış ve tutumları arasında bir bağlantı yoktur. Daha çok bireyin sosyal çevresiyle olan iletişiminin sonucu olduğunu ve bireyin üstlendiği rollerin bu ahlaki gelişimde rol oynadığını belirtir. L. Kohlberg'in sanatın kişilere ahlak eğitimi verebileceği tezinden hareketle, bu çalışma, Aesop masallarının eleştirel düşünmeyi ve ahlaki gelişimi ne kadar etkileyebileceği üzerinedir.

Anahtar Sözcükler: Fabl, ahlaki gelişim, eleştirel düşünme şekilleri, eğitim

Fables can be excellent windows for children into the worlds of animals and human beings. Moreover, they are fun to read, discuss, envisage and personalize via storytelling. There have

* Doç. Dr., Dokuz Eylül Üniversitesi, Uğur Mumcu sk., no. 5, Buca, İzmir, fcubukcu@deu.edu.tr 
been many fable theorists who have reflected on the definition of fable and its different functions. John Locke recommended fables to teach language at a time when social concern was growing, particularly in education. In the same way, the fabulist La Fontaine also alluded to the instructive aspect or value of fables. Fables are kinds of instructions disguised under the allegory of an action with the purpose of moral teaching. One of the best known theories of moral development is associated with Lawrence Kohlberg (1971), and it suggests how art might lead to moral development. Kohlberg claims that there is empirical evidence which shows that there are universal ontogenetic trends towards the development of morality. He holds, instead, that moral development is primarily the result of interaction between the individual and their social environment, where role taking is of central importance. The aim of this paper is to show how Aesop's fables are used to enhance critical thinking strategies in ELT and to promote moral development.

Aesop to whom the origination of fables is often credited is an obscure figure from classical Greek times. His moral stories were first mentioned by Aristophanes, Plato, and Aristotle in the $\mathrm{V}^{\text {th }}-\mathrm{IV}^{\text {th }}$ centuries B.C. However, these authors merely referred to these stories as a type of persuasive rhetorical form, and no contemporary collection or analysis of the genre survives. Evidence suggests that Aesop created many short moral tales, and they were passed on in the oral tradition for several centuries before being written down by Demetrius of Phalerum circa 300 B.C. (Jacobs, 1970). Subsequent translations of Aesopian fables were made by the Greeks and Romans, and later by French, German, and British writers. Thus, there are currently many variations of fables that have been printed, and it is therefore impossible to determine which are authentic Aesop fables. It is also believed by some (Perry, 1959) that Aesop probably did not append morals to the end of his fables, but later writers have added them.

A man had committed a murder and was being pursued by the victim's relatives. He reached the River Nile, and when he found a lion [other early versions have a wolf] then he was afraid and climbed up a tree; in the tree, he saw a snake and was practically scared to death, so he threw himself into the river, where a crocodile devoured him. Everything is here: the crime, the animals, the retribution. It is as if the whole Aesopic menagerie (the lion or wolf, the snake, the crocodile) conspire to enact a moral judgment. Animals work their wiles not through speech, here, but through action. These fables evoke a world of children and its challenges to the rituals and rigors of adulthood. They take parent-child relationships as their theme. Many focus on relationships of power and control central to childish fantasy. It is not simply that Aesop offers up a world in which beasts speak, or that his simple morals seem appropriate for younger ears. It is that his Fables are about children. This feature is what made the Aesopica so apposite for education, so central to the nursery and the classroom. Aesop appeals to children not just because animals talk or strange things happen, but also these tales show how to control such children. One of the most popular fables in the Middle Ages takes this question as its theme. A father has an ill-mannered, vagrant son, and so to teach him good behavior and responsibility, the fable tells a story about an old ox yoked together with a young one. The old ox asks to be removed from the yoke, for the young one is struggling against it. The farmer explains that he has yoked the two together so that the old may teach the young. In the Phadrean version, it is Aesop who steps in and tells the story to the father. In the medieval versions, the narrator himself tells it. In all cases, this is a kind of fable within a fable: a framed story that appealed, in particular, to the medieval taste for allegorical interpretation. The poem sets up fable-telling as a form of figurative instruction. It mirrors the structure of the classroom, while at the same time recalling those older idioms of labor that had made the tales of Hercules so popular among earlier children. In Walter of England's version, the sentences are short; there is almost no elision; and the vocabulary is relatively simple. The doctrine, or the teaching of the fable is as 
follows, in the commentary to the Walter of England manuscript: it is the duty of parents to teach their children that they follow them in morality and virtue through examples. The old teach the young through example and explicit instruction. Are we reading profanely or profoundly? All children's literature asks this question, though perhaps nowhere as pointedly as in the medieval Christian transformations of Aesop. That wolf, now not in sheep's but student's clothing, reappears again and again to symbolize wit and instruction pressed into the service of cupidity or vice. Those wolves are everywhere, filling the fables with their slyness. Sometimes their significance is bluntly put.

Perry $(1959,19-28)$ defines a fable in this manner: "A fable . . relates a fictitious event in the past for the obvious purpose of illustrating an ethical truth" ; "We must not confuse it with the popular animal story, of which it makes use but whose orientation is different" ; and "The teller of a fable is concerned before all else with the metaphorical meaning of his story, which he consciously aims to impart without delay". The characteristics of a fable, then, are that it (a) is short in length, (b) features talking animals as a metaphor for human actors, and (c) involves morally significant actions and outcomes that are structured in a narrative to make a moral point. In the case of "The Tortoise and the Hare" the hare is overconfident, falls asleep, and loses the race to the steadily plodding tortoise. This narrative would seem to impart the moral message that, in the domain of human actions, perseverance will be rewarded but not sloth and overconfidence.

Fables are short. This restricts the genre to narratives that involve simple plans and outcomes. Their brevity made it possible to remember and recount these stories in the oral tradition in which they were invented. In addition, this brevity also partially accounts for why they are deemed appropriate for children today. The second characteristic, talking animals, marks the story as clearly fictional and hence potentially metaphorical and also contributes to its apparent relevance for the child reader (Jose, et al., 2005). But what about the proposed metaphorical discourse force of this genre? Are children able to comprehend and appreciate fables as stories of moral didactism?

A distinction has been made by Kintsch and van Dijk (1978; van Dijk, 1980) between knowledge of the causal and logical relationships within a narrative and knowledge of the general themes or abstract principles conveyed by a narrative. Goldman (1985, 269), in a study of children's understanding of Aesop fables, termed the first text-internal reasoning and the latter text-external reasoning. She argued that comprehension of the text-internal facts (the relationships among characters' goals, actions, and outcomes) does not necessarily "ensure that higher order generalizations about the story can be or will be made". Goldman found that young children were not able to generate adequate morals for two Aesop fables, but $3^{\text {th }}$ grade and older children were able to do so. The young children, therefore, experienced difficulty in tying textinternal facts to text-external knowledge to generate morals for fables. This process is at the heart of comprehending the metaphoric message of fables, but how it works has not been explicated. First, we examine how metaphors are structured and operate as figurative devices.

Perry (1959) claimed that fables are intended to be metaphors. However, the structure of metaphors, which are typically one sentence in length, would on the surface seem to be quite dissimilar to a fable's structure. We argue that fables are metaphoric in the sense that the fable's narrative, which typically involves talking animals, is non-literal in that it conveys a message about human moral behavior, and this moral is perceived as self-relevant by listeners or readers. Winner (1988) argued that metaphor comprehension involves understanding the metaphor as an interaction between the topic and vehicle. Thus, understanding this metaphor involves deriving an appropriate and salient characteristic of the vehicle, for example, being powerful or reckless, and applying it to the topic of the sentence, the wolf. 


\section{The Narrative Structure of Fables}

Dorfman and Brewer (1994) identified two aspects of fable narratives that are necessary for understanding the fable's moral or point: (a) the positive or negative valence of the central action in the fable, and (b) the positive or negative valence of the fable's outcome.

They showed that adult readers were able to derive the fable's point by identifying the action-outcome linkages described in the text, in particular, tying an evaluation of the character's action to the positive or negative valence of the outcome. For example, in "The Tortoise and the Hare" the tortoise works hard (a positively valued characteristic) and wins the race (a positively valued outcome), whereas the hare is overconfident and lazy (negatively valued characteristics) and then loses the race (a negatively valued outcome). The reader derives the point of this fable by noting the outcome for each of the characters in the text and then identifying the generalized form of the action that resulted in this outcome. Thus, the reader reasons in this fashion: "People should do $X$, if $X$ results in a positive outcome" and "People should not do $Y$, if $Y$ results in a negative outcome". The point of the fable is as described, the moral or point of a fable is derivable from the contingency between an actor's moral behavior and the outcome that he, she, or it, experiences. However, it seems that the action-outcome linkages in most fables are not arbitrary but conform to a system of equitable rewards and punishments consistent with belief in a "just world". Lerner (1980) has described the "just world hypothesis" as the pervasive desire to believe that one lives in an orderly and fair world in which good people are rewarded and bad people are punished. We argue here that the understanding and appreciation of fables depends up this overlearned expectation. Piaget (1932/1965) showed that children readily construct moral linkages between narrative actions and outcomes. For his studies on immanent justice, stories were constructed in which a character acted in a morally bad fashion (e.g., stealing apples) and then later experienced a causally unrelated negative outcome (e.g., falling into a river). When he asked children why the outcome occurred, they often responded that "he fell in the river because he stole the apples before". Other researchers (Fein, \& Stein, 1977; Jose, 1990; Percival, \& Haviland, 1978) have argued that children not only expect a connection between bad actions and negative outcomes but also one between good actions and positive outcomes.

\section{Critical Thinking Strategies in ELT and Moral Development}

In relation to moral development through critical thinking strategies reading theorists contend that schemas closely related to the discourse guide the construction of the mental representation of the text during reading (van Dijk, \& Kintsch, 1983; Kintsch, 1988; Singer, 1994). In accordance with a constructivist perspective of human development, humans are active meaning makers in their interactions with the world around them. Through active engagement, the individual assimilates information, accommodates to new ideas, and builds conceptual networks and schemas. Schema theorists (Rumelhart, 1980; Taylor, \& Crocker, 198l; Derry, 1996) describe schemas as general knowledge structures residing in long-term memory. Schemas are formed as people notice similarities and recurrences among experiences. As organized sets of prior knowledge that are applied to new stimuli, schemas provide a top-down tool for interpreting events. In fact, they are essential to human understanding. Schemas direct perceptual scanning and provide guidance for obtaining further information. They give structure or meaning to experience by logically interrelating different aspects. They enable the perceiver to "chunk" an appropriate unit and to fill in information where information is scarce or ambiguous. They provide guidance for evaluation and problem-solving. In these ways schemas facilitate general information processing, and therefore are indispensable for reading comprehension.

In Pressley and Afflerbach's (1995) “constructively responsive reading”, readers actively 
search for meaning and construct interpretations based on prior knowledge. Consistent with similar theories of reading, Pressley and Afflerbach postulate that each reader constructs a unique representation of a text. When the text is about a familiar topic, the reader has an easier time comprehending it. On the other hand, when the text does not fit with the reader's background knowledge or schemas, readers poorly understand (Bransford, \& Johnson, 1972), misrecall (Steffensen, et al., 1979), and even distort memory of the text to fit with their schemas (Reynolds, et al., 1982).

Piaget (1932/1965) and Kohlberg (1969, 1984) studied moral thinking by presenting participants with a moral dilemma, asking what action should be taken to resolve the dilemma and why. Kohlberg classified the moral justifications that people produced into one of three levels-preconventional, conventional, and postconventional-and mapped a developmental sequence across these levels. In a similar fashion, a recent neo-Kohlbergian reformulation of moral judgment development proposes three moral judgment schemas whose development can be measured with the Defining Issues Test. These schemas are Personal Interests (making judgments based on the welfare of you and yours), Maintaining Norms (making judgments based on law and order), and Postconventional (making judgments based on higher order principles and ideals).

Developmentally based moral schemas may be considered "prior moral knowledge" about how to get along with or cooperate with others. The relationship between prior moral knowledge and moral judgment schemas has been illustrated by moral comprehension studies which measure the capacity of participants to understand moral schemas (Rest, 1973; Rest, et al., 1969; Walker, et al., 1984), regardless of whether or not the participant actually prefers to use a schema to solve a moral dilemma. Comprehension studies examine whether the participant can correctly paraphrase a reasoning statement or whether the participant distorts the statement during the response task. Correct paraphrasing of a statement indicates that the participant is capable of thinking at that level of moral reasoning. Findings support the view that comprehension of moral schemas is cumulative [i.e., a participant who comprehends a higher or more complex level also comprehends the lower or less complex levels].

Do children discern a moral theme? Although moralists like Allan Bloom (1987) propose that people read moral stories the way the authors intended, is it possible for children to do so? Several studies have examined whether children can extract the theme from a moral story. Narvaez, et al. (1998) used "found" stories to measure moral theme comprehension in $3^{\text {rd }}$ grade (8-9 year olds), $5^{\text {th }}$ grade (10-11 year olds), and college students. After the participants read and heard a story, they were presented with several tasks. First they were asked to generate a theme by writing the message of the story. Second, they were asked to select the theme for the story from a list of possible themes.Third, they were asked to select from a group of several vignettes (paragraph-long stories) the vignette with the same theme. Even after controlling for reading comprehension scores (based on a nonmoral story), significant developmental differences were evident.

Because theme extraction is so difficult for children, some researchers have examined strategies to help children learn to generalize from a story. For example, Williams, et al. (1994) demonstrated that $5^{\text {th }}$ and $6^{\text {th }}$ graders can understand the theme of a narrative, but only with extended and skillful instruction. Structured questions before, during, and after reading facilitate the comprehension of themes (Carnine, et al., 1982). Yet researchers still do not know what must occur at a fundamental level. What are the elements that are used by the reader in generalizing from a lesson? For example, perhaps the reader must link at least one character-action-outcome that is transferrable to other stories or natural events. However, educational psychologists know that children remember less of a story overall and have difficulty making inferences to connect 
goal-action-outcome chains of events (van den Broek, et al., 1997). What do we need to know in order to teach moral themes? In preliminary research using a short intervention (4 lessons in 6 weeks), in which the process of extracting a theme is described, $3^{\text {rd }}$ graders did not improve in theme extraction (P. Mogush, University of Minnesota, 2000). Regardless of the length of the intervention, there may be moral developmental stages students should undergo:

1) Awareness: This may be studied by asking these questions: What was the problem? What was the worst thing(s) the character faced?

2) Moral sensitivity to the configuration of the situation: What was going on? Who was thinking about what was going on?

3) Reasoning about possible actions: What could be done? What would happen if : : : ?

4) Personal identity: What did the character think about when deciding about or doing the deed?

5) Awareness of sacrifice: How did the action affect the character and the others?

6) Action: How did the character carry out the action?

7) Positive social outcome and the implicit or explicit positive judgment of the action: How did the story end-good or bad? Why?

Such a kind of reading is an active process because:

- Readers "get" different information from a text based on their background (e.g., skills, knowledge, expertise)

- Readers do not necessarily "get" the information or message the author intends

- Themes can be constructed by the reader but not automatically or easily

- Moral messages are a special kind of theme the reader puts together that are influenced by reading skills and moral development.

Taking into account all these points, traditional character education advocates should drop their simplistic understanding about reading moral stories to build character.While they are at it, they might also reconsider their view of character itself - as a set of traits to be developed. Such a perspective does not fit with current conceptualizations of personality (Lapsley, 1996; Cervone, \& Shoda, 1999), nor with new approaches to character education (e.g., Narvaez, et al., 2001).

\section{Aesop's Tales and Their Analysis}

1.On a cold and frosty day an ant that had laid up some corn in the summer time was bringing it out to dry.

A grasshopper, half dead with hunger, begged the ant to give him a morsel to preserve his life. "What were you doing", asked the ant, "all through last summer?" "Oh", said the grasshopper, "I was not idle. I sang all day long. "The ant laughed and, collecting her grain, said, "Since you could sing all the summer, you may dance all the winter".

What moral did Aesop draw from this story? Aesop's moral to this fable was: We should never lose a good opportunity. In other words, work while the sun shines because tomorrow it will snow. The moral clearly praises work and discourages play. Its obvious management lesson is the work ethic. The Book of Proverbs in the Jewish/Christian Bible urges us to "Take a lesson from the ants, you lazy fellow. Learn from their ways to be wise! .. They labor hard all summer, gathering food for the winter". Aesop pits play against work. In plain language, all play and no work and you don't deserve to eat. Americans have great respect for the virtue of industriousness. This fable also illustrates the most fundamental of all laws of life, that of social exchange: pay should equal effort and effort should equal pay, and action or lack of action has 
consequences. Those who have jobs sometimes unjustly argue that there are plenty of jobs, but the lazy simply don't have enough ambition to apply.

Aesop did not know that ants originated on earth millions of years ago and that there are over 15.000 species. The most primitive ants have been found preserved in amber, dating to approximately 80 million years ago. Aesop did not know that there are more ants on earth than any other insects. However, apparently he knew that his worker ant was female. At least, we might infer Aesop did because in the fable the ant is referred to as her and the grasshopper as he. Therefore, Aesop's heroine in this fable is really a female worker. All worker ants are female and usually live for about 5 or 6 years. The male ant does no work and lives only a few weeks. Male ants are good for little else than mating. Females fill the varied job assignments and do the work to make the colony survive. Ant history really is her story. Humans, unlike ants, have proven that both males and females make history and deserve equal respect.

2. Once upon a time a Wolf was lapping at a spring on a hillside, when, looking up, what should he see but a Lamb just beginning to drink a little lower down. "There's my supper", thought he, "if only I can find some excuse to seize it". Then he called out to the Lamb, "How dare you muddle the water from which I am drinking?" "Nay, master, nay", said Lambikin; "if the water be muddy up there, I cannot be the cause of it, for it runs down from you to me". "Well, then", said the Wolf, "why did you call me bad names this time last year?" "That cannot be", said the Lamb; "I am only six months old". "I don't care", snarled the Wolf; "if it was not you it was your father;" and with that he rushed upon the poor little Lamb and WARRA WARRA WARRA WARRA WARRA ate her all up. But before she died she gasped out. "Any excuse will serve a tyrant".

3. A Fox once saw a Crow fly off with a piece of cheese in its beak and settle on a branch of a tree. "That's for me, as I am a Fox", said Master Reynard, and he walked up to the foot of the tree. "Good-day, Mistress Crow", he cried. "How well you are looking to-day: how glossy your feathers; how bright your eye. I feel sure your voice must surpass that of other birds, just as your figure does; let me hear but one song from you that I may greet you as the Queen of Birds". The Crow lifted up her head and began to caw her best, but the moment she opened her mouth the piece of cheese fell to the ground, only to be snapped up by Master Fox. "That will do", said he. "That was all I wanted. In exchange for your cheese I will give you a piece of advice for the future". Do not trust flatterers".

4. The Hares were so persecuted by the other beasts, they did not know where to go. As soon as they saw a single animal approach them, off they used to run. One day they saw a troop of wild Horses stampeding about, and in quite a panic all the Hares scuttled off to a lake hard by, determined to drown themselves rather than live in such a continual state of fear. But just as they got near the bank of the lake, a troop of Frogs, frightened in their turn by the approach of the Hares scuttled off, and jumped into the water. "Truly", said one of the Hares, "things are not so bad as they seem: "There is always someone worse off than yourself". 
5. At one time the Fox and the Stork were on visiting terms and seemed very good friends. So the Fox invited the Stork to dinner, and for a joke put nothing before her but some soup in a very shallow dish. This the Fox could easily lap up, but the Stork could only wet the end of her long bill in it, and left the meal as hungry as when she began. "I am sorry", said the Fox, "the soup is not to your liking".

"Pray do not apologise", said the Stork. "I hope you will return this visit, and come and dine with me soon". So a day was appointed when the Fox should visit the Stork; but when they were seated at the table all that was for their dinner was contained in a very long-necked jar with a narrow mouth, in which the Fox could not insert his snout, so all he could manage to do was to lick the outside of the jar. "I will not apologise for the dinner", said the Stork: "One bad turn deserves another".

6. A Lion used to prowl about a field in which Four Oxen used to dwell. Many a time he tried to attack them; but whenever he came near they turned their tails to one another, so that whichever way he approached them he was met by the horns of one of them. At last, however, they fell a-quarrelling among themselves, and each went off to pasture alone in a separate corner of the field. Then the Lion attacked them one by one and soon made an end of all four: United we stand, divided we fall.

\section{Method}

\section{Participants}

The above 6 texts were used in two classes consisting of $504^{\text {th }}$ graders. Semi-structured interviews were conducted with 50 students and they were transcribed and coded later.

\section{Measures}

All participants received the following seven questions immediately after they read a story:

1) Sometimes stories are written to teach a lesson. Does this story have a lesson or a moral?

2) If yes, what is it?

3) How much did you like the main character?

4) How much did you like the outcome of the story?

5) How fair was the outcome of the story?

6) How much did you like the overall story?

7) How would you change the end or some other parts?

8) How would you rate your English class (pre- post intervention question)?

The morals provided by the participants were coded into three broad levels generally following the coding scheme devised by Dorfman and Brewer (1989). A code of 3 was given for accurate/ the most positive responses of students. The second level of response, partially correct/ partially positive, was given a code of 2 , and included responses that included aspects or parts of the accurate response but did not entirely capture the meaning of the suitable moral. The third level, inaccurate, the negative responses refer to a group of responses that do not include even a portion of the appropriate moral summary of the fable and were scored a 1 . Two researchers coded all of the morals that were given by the participants, and Cohen's kappas were computed to determine intercoder reliability. The intercoder reliability was found to be acceptable $(\kappa=.96)$. 


\section{Findings}

As to the first question, for the "have a moral?" judgment, 82\% replied "yes" for the fables. They believe that fables are didactic and teach a lesson but most do not like the the main animal character (fox and lion) (75\%) and they support the defeated ones but they add they do not wish to be in the shoes of either the victims or winners (80\%). They say the result is fair (82\%) and they express joy and satisfaction as they read the stories (100\%). As to rating the lesson, before the intervention 10 students (20\%) said it was 4, after the intervention, 32 students (64\%) said it was 4 . There is a radical rise in their enjoyment of English.

\section{Conclusion}

Observations and interviews show that students are greatly interested in reading and watching fables and they show success in understanding the moral lessons of the fables although they are not happy with the characters. Such moral lessons are believed to help the young learners to discrimate the good from the bad and to be led by moral thinking (Trabasso, \& Nickels, 1992). Proponents of character education (e.g., Lickona, 1991; Bennett, 1995; Wynne, \& Ryan, 1997) have advocated literature as an essential vehicle for the transmission of core values, as do such educators as Andrews (1994) and Tomlinson and Lynch-Brown (1996). The primary reason given for using literature in character education is the relevance to the lives of the children that literature can afford. Because many researchers emphasize that values are present in literature and in a variety of genres (Edgington, 2002), finding literature to help in values instruction is not difficult. The challenging aspect is determining how to incorporate the literature into a lesson or unit. Once they have accomplished that, however, teachers find that it is a natural and comfortable correlation. Values inculcation is the most traditional approach employed in character education. Simply stated, it is the act of transmitting to students a predetermined set of values. Values inculcation may be accomplished simply by having the students read a book with characters possessing worthy values or character traits that can be noted by the students alone or with the teacher's help. The teacher can stress the values and their importance either through reflection or through class discussion.

Valuable character traits are obvious in the fables. As the students read the fables, they can identify values such as courage, perseverance, loyalty, and responsibility. They can recognize courage. The students can cite values from the reading and then discuss their importance and application in their own lives. Values inculcation through literature helps students identify, comprehend, and apply core values. A values clarification approach to character education involves having students come to terms with their individual values preferences. They are given opportunities to cite their preferences, reflect on them, and then confirm or change their value choices. In contrast to the values inculcation method, the teacher makes no effort to determine whether the preferences are correct. Instead, the students articulate their preferences and reflect on their choices. Raths, Harmin, and Simon $(1978,114)$ present values clarification through a seven-part process:

1) Encourage students to make choices, choices which are made freely.

2) Help students to discover alternatives when they are faced with choices.

3) Help students to weigh the alternatives with care, reflecting upon the consequences.

4) Encourage students to reflect on what they prize and cherish.

5) Provide opportunities for the students to affirm their choices to others.

6) Encourage students to act and live according to their choices.

7) Help students to become conscious of patterns of behavior in their lives.

Through identifying the values, clarifying the dilemmas, gathering and organizing the evidence, considering possible consequences of each solution, and choosing among the alternatives, young 
learners can easily recognize the moral dilemmas and can easily go from comprehending the fables to evaluating them. It can be claimed that through structured guidance, students can synthesise and internalize moral values. In summary, moral judgment development is a type of generalized knowledge in the form of schemas. Moral schemas provide guidance in interpreting social experience. It is reasonable to expect that these schemas affect information processing in other contexts, such as when reading moral texts.

\section{Author's Notes}

This paper was presented in the conference "Children's Literature in Language EducationFrom Picture Books to Young Adult Fiction" between 25-27 February, 2010, Hildesheim, Germany.

\section{About the Author}

Assoc. Prof. Dr. Feryal Çubukçu got her B.A. and M.A. degrees on language teaching from Dokuz Eylul University and her Ph.D. on literary theories from Ege University. Her main interests are psycholinguistics, reading skills and strategies, cultural studies, literary theories and film studies.

\section{REFERENCES}

Aesop: The complete fables. (1998). Trans. R. Temple, \& O. Temple. New York: Penguin.

Aesop's fables. (1947). Kingsport, TN: Grosset \& Dunlap.

Aesop's fables. (1967). Trans. V. S. Vernon Jones. New York: Avenel Books.

Aesop's fables. (2003). Trans. L. Gibbs. Oxford, England: Oxford University Press.

Aesops' fables. Retrieved on January 2, 2009 from http://www.pagebypagebooks.com/Aesop/Aesops_ Fables.html

Afflerbach, P. P. (1990). The influence of prior knowledge on expert readers' main idea construction strategies. Reading Research Quarterly, 25, 31-46.

Alexander, P., \& Judy, J. (1988). The interaction of domain specific and strategic knowledge in academic performance. Review of Educuational Research, 58(4), 375-404.

Anderson, R. C., Reynolds, R. E., Schallert, D. L., \& Goetz, E. T. (1977). Frameworks for comprehending discourse. American Education Research Journal, 14(4), 367-381.

Bandura, A. (1997). Self-efficacy: The exercise of control. New York: Freeman.

Bartlett, F. C. (1932). Remembering. Cambridge: CUP.

Beach, R. (1993). A Teacher's introduction to reader-response theories. Urbana, IL: National Council of Teachers of English.

Bennett, W. (1993). The book of virtues. New York: Simon \& Schuster.

Bennett, W. (1995a). The children's book of virtues. New York: Simon \& Schuster.

Bennett, W. (1995b). The moral compass. New York: Simon \& Schuster.

Billow, R. (1975). A cognitive-developmental study of metaphor comprehension. Developmental Psychology, $11,415-423$.

Bloom, A. (1987). The closing of the American mind. New York: Simon \& Schuster.

Bransford, J. D., Brown, A. L., \& Cocking, R. R. (eds.). (1999). How people learn: Brain, mind, experience, and school. Washington, DC: National Academy Press.

Bransford, J. D., \& Johnson, M. K. (1972). Contextual prerequisites for understanding: Some investigations of comprehension and recall. Journal of Verbal Learning and Verbal Behaviour, 11, 717-726.

van den Broek, P. (1994). Comprehension and memory of narrative texts: Inferences and coherence. Ed. Gernsbacher, M. A., Handbook of Psycholinguistics, 539-588. San Diego: Academic Press.

van den Broek, P., Lorch, E., \& Thurlow, R. (1997). Children and adults’ memory for television stories: 
The role of causal factors, story-grammar categories and hierarchical level. Child Development, 67(6), 3010-3028.

Brown, A. L., Campione, J. C., \& Day, J. D. (1981). Learning to learn: On training students to learn from texts. Educational Researcher, 10, 14-21.

Carnine, D., Stevens, C., Clements, J., \& Kameenui, E. J. (1982). Effects of facilitative questions and practice on intermediate students' understanding of character motives. Journal of Reading Behaviour, 14, 179-190.

Cervone, D., \& Shoda, Y. (eds.). (1999). The coherence of personality: Social-cognitive bases of consistency, variability and organization. New York: Guilford.

Derry, S. J. (1996). Cognitive schema theory in the constructivist debate. Educational Psychology, 31(3/4), 163-174.

van Dijk, T. A. (1980). Macrostructures. Hillsdale, NJ: Erlbaum.

van Dijk, T. A., \& Kintsch, W. A. (1983). Strategies of discourse comprehension. New York: Academic Press.

Dorfman, M. H., \& Brewer, W. F. (1989). Understanding the points of fables: A developmental study (Technical Report of the Reading Research and Education Center). Urbana-Champaign: University of Illinois.

Dorfman, M. H., \& Brewer, W. F. (1994). Understanding the points of fables. Discourse Processes, 17, 105-129.

Edgington, W. (2002). To promote character education, use literature for children and adolescents. Social Studies, 113-116.

Fein, D., \& Stein, G. M. (1977). Immanent punishment and reward in six- and nine-year old children. The Journal of Genetic Psychology, 131, 91-96.

Gardner, H. (1974). Metaphors and modalities: How children project polar adjectives onto diverse domains. Child Development, 45, 84-91.

Goldman, S. R. (1985). Inferential reasoning in and about narrative texts. Ed. A. C. Graesser, \& J. B. Black. The psychology of questions, 247-276. Hillsdale, NJ: Erlbaum.

Goldman, S. R., Reyes, M., \& Varnhagen, D. (1984). Understanding fables in first and second languages. NABE J, 8(2), 35-66. Albany.

Goldman, S. R., Graesser, A. C., \& van den Broek, P. (Eds.). (1999). Narrative comprehension, causality, and coherence: Essays in honor of Tom Trabasso. Mahwah, NJ: Erlbaum.

Gorden, W. (2005). Learning from the best: From Aesop to empowerment. Vital Speeches of the Day, 71 (6), 178-184.

Harris, R. J., Lee, D. J., Hensley, D. L., \& Schoen, L. M. (1988). The effect of cultural script knowledge on memory for stories over time. Discourse Process, 11, 413-431.

Honig, W. (1987). Last chance for our children, Reading, MA: Addison-Wesley.

Jacobs, J. (1970). The fables of Aesop. New York: Burt Franklin.

Johnson, N. S. (1984). What do you do if you can't tell the whole story? The development of summarization skills. Ed. Nelson, K. E. Children's Language, 4. New York: Gardner.

Jose, P. E. (1990). Just-world reasoning in children's immanent justice judgments. Child Development, 61, 1024-1033.

Jose, P. E., \& Brewer, W. F. (1984). Development of story liking: Character identification, suspense, and outcome resolution. Developmental Psychology, 20, 911-924.

Jose, P., D’Anna, C., \& Krieg, D. B. (2005) Development of the comprehension and appreciation of fables. Genetic, Social, and General Psychology Monographs, 131(1), 5-37. Washington.

Kilpatrick, W. (1992). Why Johnny can't tell right from wrong. New York: Simon \& Schuster.

Kintsch, W., \& van Dijk, T. A. (1978). Toward a model of text comprehension and production. Psychological Review, 85, 363-394.

Kintsch, W. (1988). The use of knowledge in discourse processing: A construction-integration model. Psychological Review, 95, 163-182. 
Kintsch, W., \& van Dijk, T. A. (1978). Towards a model of text comprehension and production. Psychological Review, 85, 363-394.

Kohlberg, L. (1969). Stage and sequence: The cognitive-developmental approach to socialization. Ed. Goslin, D.. Handbook of socialization theory and research, 347-480. Chicago: Rand McNally.

Kohlberg, L. (1984). The psychology of moral development. New York: Harper \& Row.

Lapsley, D. K. (1996). Moral psychology. Boulder, CO: Westview Press.

Lehr, S. (1991). The child's developing sense of theme. New York: Teachers College Press.

Leming, J. (1997). Research and practice in character education: A historical perspective. Ed. Molnar, A., \& Rehage, K. J. The construction of children's character. Chicago: University of Chicago Press.

Lerer, S. (2007). Aesop, authorship, and aesthetic imagination. Journal of Medieval and Early Modern Studies, 37(3), 579-594. Durham.

Lerner, M. J. (1980). The belief in a just world: A fundamental delusion. New York: Plenum Press.

Lickona, T. (1991). Educating for character. New York: Bantam.

Lukens, R. (1982). A critical handbook of children's literature. IL: Scott, Foresman.

Mandler, J., \& Johnson, N. (1977). Remembrance of things parsed: Story structure and recall. Cognitive Psychology, 9, 111-151.

Martial, Epigrams. (1993). IV. 86.10-12, in D. R. Shackleton Bailey. Ed. and trans., Epigrams Cambridge, Mass.: HUP.

Narvaez, D. (2002) Does Reading Moral Stories Build Character? Educational Psychology Review, 14(2), $155-172$.

Narvaez, D. (2001). Individual differences that influence reading comprehension. Ed. Pressley, M., \& Block, C. Reading comprehension instruction, 158-175. New York: Guilford.

Narvaez, D. (1998). The effects of moral schemas on the reconstruction of moral narratives in $8^{\text {th }}$ grade and college students. Journal of Educational Psychology, 90(1), 13-24.

Narvaez, D., Bentley, J., Gleason, T., \& Samuels, J. (1998). Moral theme comprehension in third grade, fifth grade and college students. Reading Psychology, 19(2), 217-241.

Narvaez, D., Endicott, L., \& Bock, T. (in press). Who should I become? Ed. Veugelers, W., \& Oser, F. The positive and negative in moral education. New York: Routledge.

Narvaez, D., Gleason, T., Mitchell, C., \& Bentley, J. (1999). Moral theme comprehension in children. Journal of Educational Psychology. 91(3), 477-487.

Narvaez, D., \& Rest, J. (1995). The four components of acting morally. Ed. Kurtines, W., \& Gewirtz, J., Moral behavior and moral development: An introduction, 385-400. New York: McGraw-Hill.

Nash, R. J. (1997). Answering the virtuecrats: A moral conversation on character education. New York: Teachers College Press.

Perfetti, C. A. (1994). Psycholinguistics and reading ability. Ed. Gernsbacher, M. A. Handbook of Psycholinguistics, 849-894. San Diego: Academic Press.

Perry, B. E. (1959). Fable. Studium Generale, 12, 2-37.

Percival, P., \& Haviland, J. M. (1978). Consistency and retribution in children’s immanent justice decisions. Developmental Psychology, 14, 132-136.

Piaget, J. (1965, 1932). The moral judgment of the child. New York: The Free Press.

Piaget, J. (1974, 1926). The language and thought of the child. New York: The New American Library.

Pressley, M., \& Afflerbach, P. (1995). Verbal protocols of reading. NJ: Erlbaum, Hillsdale,

Raths, L. E., M. Harmin, \& S. B. Simon. (1978). Values and teaching (2nd ed.). Columbus, Ohio: Merrill.

Reynolds, R., \& Ortony, A. (1980). Some issues in the measurement of children's comprehension of metaphorical language. Child Development, 51, 1110-1119.

Richards, I. A. (1936). The philosophy of rhetoric. London: Oxford University Press.

Tomlinson, C., \& C. Lynch-Brown. (1996), Essentials of children's literature. Boston: Allyn and Bacon.

Reder, L. M., \& Anderson, J. R. (1980). Acomparison of texts and their summaries: Memorial consequences. Journal of Verbal Learning and Verbal Behavior, 19, 121-134. New York. 
Rest, J. R. (1973). The hierarchical nature of moral judgment. Journal of Personality, 41, 86-109.

Rest, J. R. (1979). Developing in judging moral issues. Minneapolis, MN: UMP.

Rest, J., Narvaez, D., Bebeau, M., \& Thoma, S. (1999a). A neo-Kohlbergian approach to moral judgment: An overview of defining issues test research. Educational Psychology Review, 11(4), 291-324.

Rest, J. R., Narvaez, D., Bebeau, M., \& Thoma, S. (1999b). Postconventional moral thinking: A neoKohlbergian approach. NJ: Erlbaum, Mahwah.

Rest, J., Turiel, E., \& Kohlberg, L. (1969). Level of moral development as a determinant of preference and comprehension of moral judgment made by others. Journal of Personality, 37, 225-252.

Reynolds, R., Taylor, M., Steffensen, M., Shirey, L., \& Anderson, R. (1982). Cultural schemata and reading comprehension. Reading Research Questions, 17, 353-366.

Rosenblatt, L. M. (1938/1983). Literature as exploration. New York: MLA.

Rumelhart, D. E. (1980). Schemata: The building blocks of cognition. Ed. Spiro, R. J., Bruce, B. C., \& Brewer, W. F. Theoretical issues in reading comprehension, NJ: Erlbaum, Hillsdale.

Singer, M. (1994). Discourse inference processes. Ed. Gernsbacher, M. A. Handbook of psycholinguistics, 479-516. New York: Academic Press.

Steffensen, M., Joag-Dev, C., \& Anderson, R. (1979). Across-cultural perspective on reading comprehension. Reading Research Questions, 15, 10-29.

Stein, N. L., \& Glenn, C. G. (1979). An analysis of story comprehension in elementary school children. Ed. Freedle, R. New directions in discourse processing, 4, 53-119. NJ: Ablex, Norwood.

Taylor, K. (1986). Summary writing by young children. Reading Research Questions, 21, 193-207.

Taylor, S. E., \& Crocker, J. (1981). Schematic bases of social information processing. Ed. Higgins, E. T., Herman, C. P., \& Zanna, M. P. Social cognition: The Ontario symposium, vol. 1, 89-134. NJ: Erlbaum, Hillsdale.

Trabasso, T., \& Nickels, M. (1992). The development of goal plans in the narration of a picture story. Discourse Processes, 15, 249-275.

Walker, L., de Vries, B., \& Bichard, S. L. (1984). The hierarchical nature of stages of moral development. Developmental Psychology, 20, 960-966.

Williams, J. P., Brown, L.G., Silverstein, A. K., \& de Cani, J. (1994). An instructional program in comprehension of narrative themes for adolescents with learning disabilities. Learning Disability Quarterly, 17, 205-221. Kansas City.

Winner, E. (1988). The point of words: Children's understanding of metaphor and irony. Cambridge, MA: Harvard University Press.

Wynne, E. A., \& K. Ryan. (1997). Reclaiming our schools: Teaching character, academics, and discipline (2nd ed.). Upper Saddle River, N.J.: Prentice-Hall.

Wynne, E., \& Ryan, K. (1993). Reclaiming our schools. New York: Merrill. 